\title{
Correction \\ Correction: Salazar-Cubillas, K.C.; Dickhoefer, U. Evaluating the Protein Value of Fresh Tropical Forage Grasses and Forage Legumes Using In Vitro and Chemical Fractionation Methods. Animals 2021, 11, 2853
}

\author{
Khaterine C. Salazar-Cubillas ${ }^{1}$ (D) and Uta Dickhoefer ${ }^{1,2, *}$ \\ 1 Institute of Agricultural Sciences in the Tropics (Hans-Ruthenberg-Institute), Animal Nutrition and \\ Rangeland Management in the Tropics and Subtropics, University of Hohenheim, 70599 Stuttgart, Germany; \\ khaterine.salazar-cubillas@uni-hohenheim.de \\ 2 Institute of Animal Nutrition and Physiology, Christian-Albrechts-Universität zu Kiel, 24118 Kiel, Germany \\ * Correspondence: aninutrop@uni-hohenheim.de; Tel.: +49-711-459-23650; Fax: +49-711-459-23702
}

check for updates

Citation: Salazar-Cubillas, K.C.; Dickhoefer, U. Correction:

Salazar-Cubillas, K.C.; Dickhoefer, U. Evaluating the Protein Value of Fresh Tropical Forage Grasses and Forage Legumes Using In Vitro and Chemical Fractionation Methods. Animals 2021, 11, 2853. Animals 2022, 12, 173. https://doi.org/ 10.3390/ani12020173

Received: 23 November 2021

Accepted: 3 December 2021

Published: 12 January 2022

Publisher's Note: MDPI stays neutral with regard to jurisdictional claims in published maps and institutional affiliations.

Copyright: () 2022 by the authors Licensee MDPI, Basel, Switzerland. This article is an open access article distributed under the terms and conditions of the Creative Commons Attribution (CC BY) license (https:// creativecommons.org/licenses/by/ $4.0 /)$.

\section{Error in Figure/Table}

The authors wish to make the following correction to their paper [1]. In the Results section, Table 2 was incorrect due to some errors with the location of numbers. The correct version of the table appears below. The authors apologize for any inconvenience; the change does not affect the scientific results on the animal level.

Table 2. Predictions of the post-ruminal crude protein (PRCP) supply as estimated with the reference and in vitro methods at rumen passage rates of 2,5 , and $8 \% / \mathrm{h}$ and as calculated with the chemical method using the equation of Zhao and Cao [5] at rumen passage rate of $5 \% / \mathrm{h}$ of fresh tropical forage grasses and legumes.

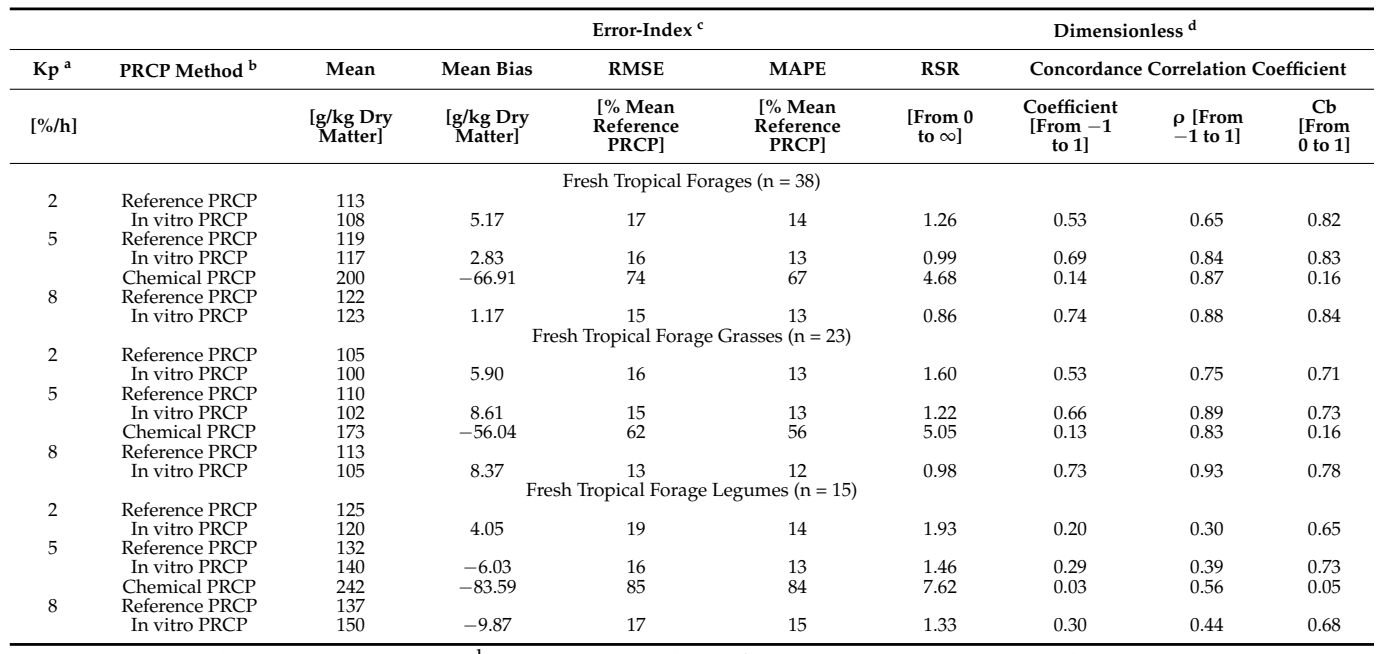

a Passage rates through the rumen. ${ }^{b}$ PRCP methods: reference PRCP, PRCP supply determined at rumen passage rates of 2,5 , and $8 \% / \mathrm{h}$ with the equation $\mathrm{N}^{\circ} 11$ of Lebzien et al. [15] using information on in situ rumen-undegraded crude protein at rumen passage rates of 2,5 and $8 \% / h$, crude protein, and digested organic matter concentration determined from in vitro gas production; in vitro PRCP, PRCP supply estimated with the in vitro method [4]; chemical PRCP, PRCP supply calculated from concentrations of crude protein fractions using the equation of Zhao and Cao [5] for dried forage grasses, a grass silage, a fresh forage legume, and corn and soybean by-products. Results from the chemical method were only compared at a rumen passage rate of $5 \% / \mathrm{h}$, because the method was validated against a PRCP measurement after $24 \mathrm{~h}$ in vitro incubation, which resembles a PRCP supply at a rumen passage rate of $5 \% / \mathrm{h}$. ${ }^{\mathrm{c}}$ Error-index measurements include measures on mean bias, root mean square error (RMSE), and mean absolute percentage error (MAPE). ${ }^{\mathrm{d}}$ Dimensionless; includes measures such as the ratio between root mean square error and standard deviation (RSR), the concordance correlation coefficient $(\mathrm{CCC})$, and its partitioning into correlation coefficient $(\rho$, i.e., precision) and bias correction factor $(\mathrm{Cb}$; i.e., accuracy). 
The authors would like to apologize for any inconvenience to the readers caused by these errors.

\section{Reference}

1. Salazar-Cubillas, K.C.; Dickhoefer, U. Evaluating the protein value of fresh tropical forage grasses and forage legumes using in vitro and chemical fractionation methods. Animals 2021, 11, 2853. [CrossRef] [PubMed] 